\title{
THE ROLE OF SHARIA BANKS IN DEVELOPING THE ECONOMY IN INDONESIA
}

\author{
Masduqi \\ Sultan Agung Islamic University \\ masduqiopa@gmail.com
}

\begin{abstract}
Sharia banking whose management is based on sharia mechanisms emphasizes the vision of economic growth and economic development regarding profit sharing in accordance with the size of the contribution between the bank and the customer through a provit sharing system. So that through the Islamic banking system it is hoped that a positive synergy of economic growth and development will be formed. Where economic development places more emphasis on fundamentals for improved management and distribution between banks and customers through a proportional provit sharing system. So that it will create a system of cooperation that is mutually beneficial and at the same time stimulates economic growth and development. To be sure, in sharia banks is where profits and cost sharing are equally proportional to promoting justice. So indirectly the Islamic banks can offer product value or product proportion that is quite attractive to customers. A good customer relationship will be formed automatically with the customer so that each party can get the maximum benefits that have a direct impact on economic growth and development.
\end{abstract}

Keywords: Economy, Indonesia, Islamic banks

\section{A. INTRODUCTION}

Banking is an institution that carries out three main functions, namely accepting money deposits, lending money, and providing money transfer services. In the economic history of the Muslims, financing carried out in accordance with sharia-compliant agreements has been part of the traditions of Muslims since the time of the Prophet Muhammad. Practices such as receiving deposits, lending money for consumption and for business purposes, and sending money, have been common since the time of the Prophet. Thus, the main functions of modern banking, namely receiving deposits, channeling funds, and transferring funds have become an inseparable part of the lives of Muslims, even since the time of the Prophet.

Rasulullah SAW, known by the nickname al-Amin, was trusted by the people of Makkah to receive deposits of wealth, so that at the last moment before the Apostle migrated to Medina, he asked Sayidina Ali r.a. to return all the deposits to those who have them. ${ }^{1}$ In this concept, those who are entrusted cannot make use of the said assets. As the role of the Prophet Muhammad was sent in the world is a

1 Sami Hamoud, Islamic Banking, London: Arabian Information Ltd, 1985, P. 12 
sacred mission affirmed in the Qur'an to be generous as whole beings human beings. $^{2}$

A companion of the Prophet, Zubayr bin al Awwam, chose not to accept the deposit of property. He prefers to receive it in the form of a loan. Zubair's actions have different implications: first, by taking the money as a loan, he has the right to use it; second, because it is in the form of a loan, it is obliged to return it intact. ${ }^{3}$ Another friend, Ibn Abbas was recorded doing a money transfer to Kufa. It was also recorded that Abdullah bin Zubair in Makkah also sent money to his brother Misab bin Zubair who lived in Iraq.

The use of checks is also wellknown in line with the increasing trade between Sham and Yemen, which at least takes place twice a year. Even in the days of Umar bin Khattab r.a, he used checks to pay benefits to those who were entitled. With this check they then took the wheat in Baitul Mal which was then imported from Egypt. In addition, the provision of capital for profit-based working capital, such as mudaraba, musharaka, muzara'ah, musaqah, was known from the beginning among the Muhajirin and the Ansar.

The use of checks is also wellknown in line with the increasing trade between Sham and Yemen, which at least takes place twice a year. Even in

2 Djauhari, STUDY THE THEORY OF WELFARE STATE IN WEST AND ISLAMIC PERSPECTIVE, Jurnal Pembaharuan Hukum, Volume V No.3 September-Desember 2018, P.411-425.

3 Sudin Haron, Prinsip dan Operasi Perbankan Islam, Kuala Lumpur; Berita Publishing Sdn Bhd, 1996, P. 2 the days of Umar bin Khattab r.a, he used checks to pay benefits to those who were entitled. With this check they then took the wheat in Baitul Mal which was then imported from Egypt. ${ }^{4}$ In addition, the provision of capital for profit-based working capital, such as mudaraba, musharaka, muzara'ah, musaqah, was known from the beginning among the Muhajirin and the Ansar.

It is clear that there are individuals who have carried out banking functions in the time of the Prophet Muhammad, even though these individuals did not carry out all banking functions. There are friends who carry out the function of receiving deposits, there are friends who carry out the function of borrowing and borrowing money, there are those who carry out the function of sending money, and some are providing working capital.

The importance of banks during the time of the Messenger of Allah and companions shows the importance of Islamic banks. Likewise, Islamic banks in Indonesia have an important role in developing the economy in Indonesia, which is a matter of what are the roles of Islamic banks in developing the economy in Indonesia.

Banking institution that serves as a collecting and distributing public funds (financial intermediary) have a strategic role to support the implementation of national development, namely in order to

4 Kadim Sadr, Money and Monetary Policies in Early Islam", dalam Abbas Mirakhor dan Baqir AlHasani, 1989, Essay on Iqtisad: An Islamic Approach to Economic Problems, Silver Spring: Nur Copr, P.14. 
improve the distribution of development. In 1997, Southeast Asia experienced a financial crisis that could change Indonesia's economy collapsed. This has an impact to companies that exist in the country, especially in the banking sector at the time. Banking institutions is one of the backbone of the economy of a country because it serves as intermediary institutions increasingly affected. ${ }^{5}$

\section{B. RESEARCH METHODS}

This writing uses library research (qualitative research), and is qualitative, descriptive analysis. Literature research, which examines a number of literature relevant to the problem of this writing. Data analysis used in this study is descriptivequalitative by analyzing data / information obtained through descriptive research with library research which is then systematically compiled and described qualitatively. ${ }^{6}$

\section{DISCUSSION}

Islamic banking is now widely known in the Muslim and Western world. $^{7}$ The development of Islamic banks in Islamic countries influenced Indonesia. In the early 1980s,

5 Elvira Fitriyani Pakpahan, LEGAL PROTECTION AGAINST DEPOSITORS' CUSTOMERS WITH MUDHARABAH CONTRACT ON ISLAMIC BANKS, Jurnal Pembaharuan Hukum, Volume VI No.1 Januari-April 2019, P.45-53.

6 Andi Aina Ilmih, A.Zulkarnain, IDEAL ELECTRONIC CONTRACT MODEL AS A FORM OF E-COMMERCE DISPUTES SETTLEMENT, Jurnal Pembaharuan Hukum Volume VI No.1 JanuariApril 2019, P.77-89.

7 Abdullah Saeed, Bank Islam dan Bunga, terj. Muhammad Ufuqul Mubin, Nurul Huda, Ahmad Sahidah, Yogyakarta: Pustaka Pelajar, 2013, P. 1. discussions about Islamic banks as pillars of Islamic economics began. The figures involved in the study were Karnaen A Perwataatmadja, M. Dawam Rahardjo, AM. Saefuddin, M. Amien Azis, and others. ${ }^{8}$ Several trials on a relatively limited scale have been realized. Among them was Baitut Tamwil-Salman, Bandung, which had grown impressively. In Jakarta a similar institution was formed in the form of a cooperative, the Ridho Gusti Cooperative.

However, a more specific initiative to establish an Islamic bank in Indonesia was only carried out in 1990. The Indonesian Ulema Council (MUI) on 18-20 August 1990 held a Workshop on Bank and Banking Interest in Cisarua, Bogor, West Java. The results of the workshop were discussed in more depth at the IV MUI National Conference which took place at the Sahid Jaya Hotel Jakarta, August 22-25, 1990. Based on the mandate of the MUI IV National Conference, a working group was formed to establish an Islamic bank in Indonesia. The working group, called the MUI Banking Team, is tasked with approaching and consulting with all relevant parties.

Bank Muamalat Indonesia was born as a result of the MUI Banking Team mentioned above. The Deed of Establishment of PT Bank Muamalat Indonesia was signed on November 1 , 1991. At the time of the signing of this deed, a share purchase commitment of Rp 84 billion was collected.

8 Abdullah Saeed, Bank Islam dan Bunga, terj. Muhammad Ufuqul Mubin, Nurul Huda, Ahmad Sahidah, Yogyakarta: Pustaka Pelajar, 2013, P. 1. 
On November 3, 1991, the President's event at the Bogor Palace was met with a total initial capital commitment of Rp. 06,126,382,000.00. With this initial capital, on May 1, 1992, Bank Muamalat Indonesia began operations. Until September 1999, Bank Muamalat Indonesia had more than 45 outlets spread across Jakarta, Bandung, Semarang, Surabaya, Balikpapan, and Makassar. ${ }^{9}$

At the beginning of the establishment of Bank Muamalat Indonesia, the existence of Islamic banks did not receive optimal attention in the national banking industry. The legal basis of bank operations using the sharia system is only categorized as "banks with profit sharing systems"; there are no details of the legal basis of sharia and the types of businesses that are permitted. This is very clearly reflected in Law No. 7 of 1992, in which the discussion of banking with the production sharing system is described only in passing and is a mere "insert".

However, the development of sharia banking in the reform era was marked by the approval of Law No. 10 of 1998. The law stipulates in detail the legal basis and types of businesses that can be operated and implemented by Islamic banks. The law also provides direction for conventional banks to open shari'ah service units or even convert themselves totally into sharia banks.

The opportunity was apparently welcomed enthusiastically by the banking community. A number of banks have begun to provide training in sharia

9 Bank Muamalat, Annual Report, Jakarta, 2009, P.26 banking to their staff. Some of these banks want to explore to open shari'ah divisions or branches in their institutions. Some even plan to convert themselves completely into sharia banks. This was anticipated by Bank Indonesia by conducting "Sharia Banking Training" for Bank Indonesia officials from all sections, especially those directly related to the apparatus such as DPNP (Directorate of Banking Research and Regulation), credit, supervision, accounting, research, and monetary. The reason for the public responding positively to the emergence of Islamic banks is that their halal levels are more guaranteed, Islamic banks in their operations are without interest but profit sharing systems, another because conventional banks are unable to survive in times of economic crisis, even conventional banks take part in the deterioration of the national economy.

Then Bank Syari'ah Mandiri (BSM) is the first state-owned bank that bases its operations on sharia principles. Structurally, BSM came from Bank Susila Bakti (BSB), as a subsidiary in the scope of Bank Mandiri (ex BDN), which was later converted into a full Islamic bank. In order to expedite the process of conversion into a sharia bank, BSM cooperates with the Tazkia Institute, especially in the field of conversion training and assistance.

As one of the banks owned by Bank Mandiri which has assets of Rp 155 trillion (one hundred fifty-five trillion) and extensive networking, BSM has several comparative advantages over its predecessor. Likewise, the latest political developments in Aceh became a blessing in disguise for BSM. 
This is because BSM will surrender all branches of Bank Mandiri in Aceh to BSM for sharia management. This big step will clearly inflate BSM assets from the position at the end of 1999 in the amount of Rp.400,000,000,000.00 (four hundred billion rupiah) to above 2 to 3 trillion. This development was also followed by an increase in the number of BSM branches, from 8 to more than 20 units. One other development of sharia banking in Indonesia is the permissibility of converting conventional commercial bank branches into sharia branches.

Provisions regarding bank business activities based on sharia principles in Law No.7 of 1992 are very limited, namely only concerning financing activities and are not regulated regarding fund raising. Then it is regulated in the new law more clearly, completely, and more explicitly / both with regard to raising funds and providing financing.

In Law No. 10 of 1998 concerning Amendment to Law No. 7 of 1992 concerning Banking, there are several changes that provide greater opportunities for the development of sharia banking. From this law, we can capture that the sharia banking system was developed with the following objectives, among others.

1. Meet the needs of banking services for people who cannot accept the concept of interest. With the implementation of the shari'ah banking system that is side by side with the conventional banking system, the mobilization of public funds can be done more broadly, especially from segments that have so far not been able to be touched by conventional banking systems that apply the interest system.

2. Opening financing opportunities for business development based on the principle of partnership. In this principle, the concept applied is a harmonious investor relationship (mutual investor relationship). While in conventional banks the concept applied is the relationship between the debtor and the creditor (debtor to creditor relationship).

3. Meeting the need for banking products and services that have several comparative advantages in the form of eliminating perpetual interest, limiting unproductive speculation, financing aimed at businesses that pay more attention to moral elements.

Some important changes in Law No. 10 of 1998, among others, as follows:

1. In the context of expanding the reach of banking services by rural credit banks, especially for the weak economy group / small entrepreneurs who in reality are both in rural and urban areas, the requirement that the establishment and or opening of people's credit bank offices must be carried out in the sub-district area be abolished. Thus, BPRs can be established and open offices in all regions of Indonesia.

2. Commercial banks and people's credit banks can carry out 
business activities conventionally or based on sharia principles. Especially for commercial banks that have been running conventional business activities can open full branches (full branch\} for business activities based on sharia principles.

With the inclusion of sharia principles in the banking system (public credit banks), it is expected to truly accommodate the operations of Islamic banks. In line with that, it is also hoped that development, guidance and socialization by Bank Indonesia will be more optimal. Of course, the next impact is also expected on the development of BMT financial institutions.

In addition to the laws and regulations, Islamic financial institutions such as BPRS and BMT have more opportunities compared to conventional banks because of the following matters, among others:

1. Shari'ah financial institutions are carried out with the principles of fairness, fairness and rationality, where the benefits provided to depositing customers are properly derived from the benefits of using funds by entrepreneurs of sharia financial institutions. With this pattern, sharia financial institutions avoid negative spreads, like conventional banks.

2. Sharia financial institutions have a mission that is in line with government programs, namely the empowerment of the people's economy, so that there is an opportunity to establish mutually beneficial cooperation in the achievement of each goal. We know that the government is currently actively developing an economy based on populist economy through program credits such as KKPA for Profit Sharing, Working Capital Financing (PMK) of BPRS, Financing for Small and Micro Entrepreneurs (PPKM). This opens up opportunities for BPRS / BMT to develop partnership patterns. ${ }^{10}$

3. As long as the borrowing customer and the user of the fund adhere to the principle of profit sharing system, the sharia system is actually resistant to economic waves. Islamic financial institutions do not recognize the pattern of exploitation by fund owners to users of funds in the form of high interest costs as applies to conventional systems. ${ }^{11}$

The purpose of Islamic banks is to spur economic development and social progress of member countries and Muslim societies, both individually and collectively, while the main objective of the establishment of Islamic banks is to avoid interest rates carried out by conventional banks (Conventional Banks), As for the benefits or uses of Islamic banks are as follows:

a. Participating in balanced capital from productive ventures in member countries, investing in

10 Rachmat Syafe'i, Fiqih Muamalah, Bandung: Pustaka Setia, 2011, hlm. 276

11 Zainul Arifin, Memahami Bank Syariah Lingkup, Peluang, Tantangan dan Prospek, Jakarta: Alvabet, 2012, hlm 135-137 
economic and social infrastructure projects in member countries through participation;

b. Providing loans to the private and state sectors to finance productive business projects and programs;

c. Establish and operate special funds for special needs, including social funds to help Muslim communities who are outside members;

d. Providing technical assistance to member countries and promoting international trade;

e. Conducting research so that economic, financial and banking activities in Islamic countries can be adjusted to the provisions of the Shariah;

f. The bank tries to find an appropriate ratio to maintain a suitable ratio between investments given to member countries;

g. The Bank will retain its rights and freedom to sell its investment shares;

h. Trying to maintain a reasonable diversity in investment;

i. Collect a fee for his services to cover administrative costs. ${ }^{12}$

Referring to the explanation above, it can be concluded that the sharia bank in terms of historical aspects, it was born and developed as a result of the agreement of the Muslims represented by Muslim scholars and scholars. This means the community, especially the Islamic community needs to continue to support it. Because only from the support of the Islamic banking community still exist.

Enactment of Law no. 10 of 1998 concerning changes to Law No. 7 of 1992 concerning Banking, and Law No. 21 of 2008 concerning Sharia Banks, which was followed by the issuance of a number of implementing regulations in the form of a BI Board of Directors Decree / Bank Indonesia Regulation, has provided a stronger legal basis for the development of sharia banking in Indonesia. These regulations provide ample opportunity to develop sharia banking networks, among others through permits to open sharia branch offices (KCS) by conventional banks. In other words, commercial banks can carry out two business activities, both conventionally and based on sharia principles.

July 16, 2008, Law No. 21 of 2008 concerning Sharia Banking. The ratification of this law provides the legal basis for the national sharia banking industry and is expected to be able to encourage the development of the sharia banking industry to be better because the target of achieving a national banking market share of $5 \%$ has not been able to be achieved in 2009. One of the crucial things in the law This law is able to accelerate the development of sharia banking in Indonesia, which is related to the spin-off of sharia business units, both voluntary and mandatory if the assets of sharia business units have reached

12 Nejatullah Shiddiqi, Pemikiran Ekonomi Islam, Alih Bahasa A.M. Saefuddin, Jakarta: LIPPM, 1986, P. $82-84$ 
$50 \%$ of the assets of the parent bank. ${ }^{13}$

With Law No. 10 of 1998 a strong legal foundation has been established and guarantees legal certainty for economic actors and the wider community for institutions and business activities of Islamic banks. These provisions are as follows:

1) Arrangement of institutional aspects and business activities and sharia banks as stipulated in article 1 paragraph 3 of Law No. 10 of 1998, the Article explains that commercial banks can choose to conduct business activities based on conventional systems or based on sharia principles or to do both activities. In the case of a commercial bank conducting business based on sharia, the activity is carried out by opening a special work unit and branch office, namely sharia business units and sharia branch offices. Whereas BPR must choose one of the activities as conventional or sharia BPR. Conventional commercial banks that will open sharia branches must implement:

- Has a Sharia Supervisory Board which is placed by the National Sharia Council (DSN), and

- Providing working capital set aside by banks in a separate account in the name of UUS which can be used to pay office expenses and others related to KCS operational

13 M. Nur Rianto Al-Arif, Ekonomi Syari'ah Teori dan Praktik, Bandung: Pustaka Setia, 2013, P.325. and activities.

non-operational

2) Provisions for clearing monetary instruments and interbank money markets. In the explanation of Law No. 23 of 1999 concerning Bank Indonesia has mandated that to anticipate developments based on sharia principles, the duties and functions of BI need to accommodate sharia principles. This can be seen in article 10 (2) which determines that the implementation of BI's tasks in the field of monetary control can be carried out based on sharia principles. In addition, Article 11 stipulates that in its function as the lender of the last resort, BI can provide financing based on sharia principles for a maximum period of 90 days to sharia banks to overcome the short-term funding difficulties of the relevant bank. In this regard, BI has compiled provisions relating to the operation of sharia banks, namely:

- Provisions on the statutory reserve requirement for conventional banks that open KCS.

- Clearing Provisions.

- Interbank financial market provisions are based on sharia principles (PUAS).

- Wadiah B I. Provisions

To support smooth inter-bank payment traffic and the implementation of PUAS, payment transactions are carried out through a clearing mechanism by imposing a checking account on BI. If the clearing of bank balances becomes less than the Statutory Reserves, the bank or branch office is subject to financial penalty. If 
the balance becomes negative, the relevant bank, including its branches, will be subject to sanctions for terminating the clearing participants plus an obligation to pay.

In operational activities, banks may experience excess or lack of liquidity. If there is excess, then the bank places excess liquidity so that the bank makes a profit. Conversely, if experiencing liquidity shortages, banks need facilities to cover liquidity shortages in the context of financing activities so that bank operations can run well. Sharia banks that experience a shortage of funds can issue an Interbank Mudarabah Investment Certificate (IMA) which is a means of investing funds for Islamic banks and conventional banks. To maintain monetary stability, BI absorbs excess liquidity of sharia banks through the issuance of Bank Indonesia Wadiah Certificates (SWBIs) which are based on the principle of depositing trusts (wadiah). From the syariah bank point of view, the device is a means / temporary placement of excess liquidity, before managed funds can be channeled for financing. ${ }^{14}$

In line with Indonesia's national development goals to improve the economy in order to achieve the creation of a just and prosperous society based on economic democracy, an economic system was developed based on the values of justice, togetherness, equality, and benefits in accordance with sharia principles. The needs of the Indonesian people for

14 Bank Indonesia, Perbankan Syariah Nasional, Kebijakan dan Pengembangan, Jakarta: Bank Indonesia, Jakarta, P. 7-11. sharia banking services are increasing; that shari'ah banking has specificity compared to conventional banking, the regulation regarding sharia banking in Act Number 7 of 1992 concerning Banking as amended by Act Number 10 of 1998 has not been specific so a separate law was created regarding syari'ah banking namely Law No. 21 of 2008 concerning Sharia Banks.

Bringing prosperity to the people in Indonesia is not an easy matter to realize. The role taken to make it happen through economic development can be done evenly in all regions not only involving the government, but must take the role of the existing banks. Banks operating in Indonesia have experienced a system expansion with banks operating using sharia principles and conventional ones. However, measuring the age of Islamic banks that are not so old when compared to conventional banks raises questions to see its role in developing the economy.

Islamic banks which, although functionally similar to conventional banks, are collecting and channeling funds, the concept used has a difference that is using a profit sharing system and does not justify the practice of usury or interest to be applied in its operations. In addition, justice cases also become a reference for Islamic banks so that relationships that are built to the community are not harmed through fraudulent, non-transparent, speculative and other acts that are prohibited in sharia principles.

The Islamic banks in Indonesia also bear responsibility for their existence, which not only carries out operations based on sharia principles, 
but also has extensive influence in developing the economy. The issue of developing the economy is how Islamic banks can develop the economic potential of the community so that it can grow properly. This is based on the fact that fluctuations in economic movements that are so volatile often occur in Indonesia. So, at any time it can cause economic sluggishness in the community which increases which has a bad influence in the form of failure to achieve national economic growth. The market share that can be entered by Islamic banks in general can be to meet the needs of their customers in the form of consumer financing and productive financing to develop a managed business. However, to be able to take the role as the motor of economic development for the community, Islamic banks can be balanced in dividing the portion of financing between consumptive and productive.

Balance in the provision of financing is needed so that the economy in the community can run properly. It can be imagined if the provision of financing is only dominated by meeting the demand for housing and vehicles, then the fate of the people who need capital to develop their businesses will not get access. Therefore, this can indeed be a consideration to be able to boost the existing economic growth among the people who are in business in various sectors and different business levels. Therefore, if the economic potential in the community can be driven through the provision of financing by Islamic banks, it can be an opportunity for Islamic banks to expand their operations. In addition, by looking at the performance of Islamic banks that can see economic opportunities through the provision of financing to businesses engaged in various sectors that do not come out of the sharia corridor, it can increase the level of public confidence in Islamic banks.

With the high level of trust owned by Islamic banks from the public, indirectly, in addition to increasing the number of people who apply for financing, it can also increase the number of people saving at Islamic banks. Therefore, it can simultaneously be said that if the economic growth in the community is going well, the potential of the community to save also increases. This has also become a part in the framework of developing the existing economy in the community so that the level of welfare in all regions can increase and can reduce the number of poor people.

But also in developing the economy in the community through the provision of financing is not without problems borne by the Islamic bank. The problem is more to the fear arising from financing that is experiencing obstacles during the return process. This incident if done by many customers who get financing can disrupt the level of liquidity of the Islamic bank itself which must have more funds reserved for possible financing problems occur. So if the economic conditions are in place, it also indirectly hits the Islamic banks because of the increasing level of problematic financing which indicates the economy in the community is not good. 
Therefore, Islamic banks that do not use the interest system in their operations but replace it with the concept of profit sharing and actual margins, according to many opinions have the potential to be better in advancing the economy in society. With the growth of sharia banks, the position it has taken is to be more active in channeling financing to various sectors that have the potential to develop its economy and to be able to build an even better economy. In the real economic sector, Islamic banks have a role in increasing national development, with the prohibition of using the interest rate system in their operations, then directly managed by Islamic banks will be channeled to the real sector which will automatically play a role in the national development process.

In addition, Islamic banks also have a role and role in attracting other countries' investment to Indonesia, so that Islamic investment opportunities that are considered large enough in Indonesia can attract foreign countries to invest by investing in Indonesia. This through the Islamic banking investment sector will provide benefits for Indonesia directly, so that national development will further develop rapidly.

On the other hand, by prioritizing the principle of the prohibition of usury, as well as prioritizing the truth, and the precautionary principle applied by Islamic banks in their operations, these things form ethical economic behavior in people's lives. So that with the principle of justice for all parties applied by Islamic banks in the implementation of their business activities, it will also indirectly have a good impact on the national development process in Indonesia. Islamic banking has a very important role in supporting national development in Indonesia. The principles applied by Islamic banks in accordance with Islamic teachings in their business activities also have a positive impact on the process of economic development in Indonesia, which of course if national economic development develops very well there will be a rapid increase in the welfare and prosperity of the Indonesian people.

\section{CONCLUSION}

Islamic banks that do not use the interest system in their operations but replace it with the concept of profit sharing and actual margins, according to many opinions have the potential to be better in advancing economic development in society. With the growth of sharia banks, the position it has taken is to be more active in channeling financing to various sectors that have the potential to develop its economy and to be able to build an even better economy. In the real economy sector, Islamic banks have a role in increasing national development, with the prohibition of using the interest rate system in its operations, then directly managed by Islamic banks will be channeled to the real sector which will automatically play a role in the process of economic development in Indonesia. 


\section{BIBLIOGRAPHY}

Abdullah Saeed, 2013, Bank Islam dan Bunga, terj. Muhammad Ufuqul Mubin, Nurul Huda, Ahmad Sahidah, Pustaka Pelajar, Yogyakarta;

Andi Aina Ilmih, A.Zulkarnain, IDEAL ELECTRONIC CONTRACT MODEL AS A FORM OF ECOMMERCE DISPUTES SETTLEMENT, Jurnal Pembaharuan Hukum Volume VI No.1 Januari-April 2019;

Bank Indonesia, Perbankan Syariah Nasional, Kebijakan dan Pengembangan, Jakarta: Bank Indonesia, Jakarta;

Bank Muamalat, 2009, Annual Report, Jakarta;

Djauhari, STUDY THE THEORY OF WELFARE STATE IN WEST AND ISLAMIC PERSPECTIVE, Jurnal Pembaharuan Hukum, Volume V No.3 September-Desember 2018;

Elvira Fitriyani Pakpahan, LEGAL PROTECTION AGAINST DEPOSITORS' CUSTOMERS WITH MUDHARABAH CONTRACT ON ISLAMIC BANKS, Jurnal Pembaharuan Hukum, Volume VI No.1 Januari-April 2019

Kadim Sadr, Money and Monetary Policies in Early Islam", dalam Abbas Mirakhor dan Baqir Al-Hasani, 1989, Essay on Iqtisad: An Islamic Approach to Economic Problems, Silver Spring: Nur Copr;

M. Nur Rianto Al-Arif, 2013, Ekonomi Syariah Teori dan Praktik, Bandung: Pustaka Setia, bandung;

Nejatullah Shiddiqi, 1986, Pemikiran Ekonomi Islam, Alih Bahasa A.M. Saefuddin, Jakarta: LIPPM,

Rachmat Syafe'i, 2011, Fiqih Muamalah, Pustaka Setia, Bandung;

Sami Hamoud, 1985, Islamic Banking, London: Arabian Information Ltd;

Sudin Haron, 1996, Prinsip dan Operasi Perbankan Islam, Kuala Lumpur; Berita Publishing Sdn Bhd;

Zainul Arifin, 2012, Memahami Bank Syariah Lingkup, Peluang, Tantangan dan Prospek, Alvabet, Jakarta: 